\title{
ROLE OF AGE, SEX, AND BODY MASS INDEX ON BLOOD PRESSURE AMONG STUDENTS OF ST. HENDRIKUS HIGH SCHOOL, SURABAYA, INDONESIA
}

\author{
Susilowati Andajani \\ Department of Public Health and Preventive Medicine, Faculty of Medicine, Universitas Airlangga, Surabaya, \\ Indonesia
}

\section{ABSTRACT}

The purpose of this study was to analyze the influence of age, sex, Body Mass Index (BMI), and nutritional status on blood pressure in class X and XI students, SMAK St. Hendrikus, Surabaya, Indonesia. The sample of students in class X and XI of SMAK St. Hendrikus Surabaya in 2013. The sample size was 150 students. The sampling technique was consecutive sampling. The independent variables were age, sex, BMI, and nutritional status, while the dependent variable was blood pressure. Data were analyzed by Pearson correlation test, Spearman, and Chi Square statistical test with ?=0.05. The level of risk was calculated by epi info program. Most students (40.7\%) were 16 years old, those with pre-hypertension (systolic) 26.7\%, grade 1 systolic hypertension by $1.3 \%$, diastolic pre-hypertension $25.3 \%$ and grade 1 diastolic hypertension by $6.7 \%$. Age did not have significant influence $(p=0.623)$ on systolic blood pressure, but had a significant influence $(p=0.002)$ on diastolic blood pressure. Male sex significantly influenced systolic ( $p=0.002$, RR $5.3695 \%$ CI 2.2320-12.8649) and diastolic ( $p<0.001$, RR $1.9595 \%$ CI 1.1272-3, 3719) blood pressure. BMI had significant influence $(p<0.001)$ on blood pressure. Nutritional status had significant influence on systolic blood pressure $(p=0.002)$, with overnutrition status with RR 2.28, 95\% CI 1.3983-3.7104. Nutritional status had significant influence on diastolic blood pressure ( $p<0.001$ ), and with overnutrition status with RR 2.73 , 95\% CI 1.8143-4.1179. In conclusion, the trend for pre-hypertension to grade 1 diastolic hypertension increases with age and age has an influence on diastolic blood pressure. The risk of males to have pre-hypertension to grade 1 systolic hypertension is 5.36 times that of females, and the risk to have pre-hypertension to grade 1 diastolic hypertension is 1.95 times that of women. The higher the BMI, the higher the systolic and/or diastolic blood pressure.

Keywords: Age; sex; BMI; nutritional status; blood pressure; students of St. Hendrikus

\section{ABSTRAK}

Tujuan dari penelitian ini adalah untuk menganalisis pengaruh usia, jenis kelamin, Indeks Massa Tubuh (BMI), dan status gizi terhadap tekanan darah pada siswa kelas X dan XI, SMAK St. Hendrikus, Surabaya, Indonesia. Sampel siswa di kelas X dan XI SMAK St. Hendrikus Surabaya pada 2013. Ukuran sampel adalah 150 siswa. Teknik pengambilan sampel adalah consecutive sampling. Variabel independen adalah usia, jenis kelamin, IMT, dan status gizi, sedangkan variabel dependen adalah tekanan darah. Data dianalisis dengan uji korelasi Pearson, Spearman, dan uji statistik Chi Square dengan? =0,05. Tingkat risiko dihitung oleh program epi info. Sebagian besar siswa (40,7\%) berusia 16 tahun, mereka yang pra-hipertensi (sistolik) 26,7\%, hipertensi sistolik grade 1 sebesar 1,3\%, pra-hipertensi diastolik 25,3\% dan hipertensi diastolik grade 1 sebesar 6,7\%. Usia tidak memiliki pengaruh yang signifikan $(p=0,623)$ pada tekanan darah sistolik, tetapi memiliki pengaruh yang signifikan $(p$ =0,002) pada tekanan darah diastolik. Jenis kelamin laki-laki secara signifikan mempengaruhi tekanan darah sistolik $(p=$ 0,002, RR 5,36 95\% 2,2320-12,8649) dan diastolik ( $p<0,001$, RR 1,95 95\% CI 1,1272-3,3719) tekanan darah. BMI memiliki pengaruh signifikan $(p<0,001)$ pada tekanan darah. Status gizi berpengaruh signifikan terhadap tekanan darah sistolik $(p=$ 0,002), dengan status kelebihan gizi dengan RR 2,28, 95\% CI 1,3983-3,7104. Status gizi memiliki pengaruh signifikan terhadap tekanan darah diastolik ( $p<0,001)$, dan dengan status kelebihan gizi dengan RR 2,73, 95\% CI 1,8143-4,1179. Kesimpulannya, tren untuk pra-hipertensi untuk hipertensi diastolik grade 1 meningkat dengan usia dan usia memiliki pengaruh pada tekanan darah diastolik. Risiko laki-laki untuk memiliki pra-hipertensi untuk hipertensi sistolik grade 1 adalah 5,36 kali dari wanita, dan risiko untuk memiliki pra-hipertensi untuk hipertensi diastolik grade 1 adalah 1,95 kali dari wanita. Semakin tinggi BMI, semakin tinggi tekanan darah sistolik dan/atau diastolik.

Kata kunci: Usia; jenis kelamin; BMI; status nutrisi; tekanan darah; siswa St. Hendrikus

Correspondence: Susilowati Andajani, Department of Public Health and Preventive Medicine, Faculty of Medicine, Universitas Airlangga, Jalan Prof dr Moestopo 47, Surabaya 60131, Indonesia.

E-mail: susilowatiandajani@yahoo.com

pISSN:2355-8393 • eISSN: 2599-056x • doi: 10.20473/fmi.v56i1.18454

- Fol Med Indones. 2020;56:67-74 • Received 28 May 2019• Accepted 14 Nov 2019

- Open access under CC-BY-NC-SA license • Available at https://e-journal.unair.ac.id/FMI/ 


\section{INTRODUCTION}

High blood pressure (hypertension) is one of the highest causes of death in the world. Complications of hypertension are estimated to cause 9.4 million deaths worldwide each year (WHO 2015). The Institute for Health Metrics and Evaluation (IHME) in 2017 stated that 53.3 million deaths in the world were mainly caused by cardiovascular disease, which was $33.1 \%$ (IHME, 2017). Hypertension is called the silent killer because it is often without complaints, so the patient does not know he is suffering from hypertension and only becomes known after complications occur. Data from the World Health Organization (WHO) in 2015 showed that around 1.13 billion people worldwide suffer from hypertension. This means that 1 in 3 people in the world is diagnosed with hypertension. The number of people with hypertension continues to increase every year along with an increase in the population, both in developing and developed countries. In 2025 it is estimated that there will be 1.5 billion people affected by hypertension (WHO, 2015).

In Indonesia in 2016 total deaths was 1.5 million with the most cause of death was cardiovascular disease (36.9\%). In 2017, out of a total of 1.7 million deaths in Indonesia, $23.7 \%$ were caused by complications of hypertension (the highest was stroke followed by ischemic heart disease) (IHME, 2017). The prevalence of hypertension in Indonesia in the population aged 18 years and older was $25.8 \%$ (Riskesdas 2013), rose to $34.1 \%$, the highest in South Kalimantan $(44.1 \%$ ), and lowest in Papua $(22.2 \%)$. The proportion of hypertensive patients in $31-44$ age group was $31.6 \%$, 45-54 years was $45.3 \%$, and 55-64 years was $55.2 \%$. The increase in the prevalence of non-communicable diseases is related to lifestyle, including smoking, consumption of alcoholic beverages, lack of physical activity, and less consumption of fruits and vegetables.

From the prevalence of hypertension of $34.1 \%$, it is known that of $8.8 \%$ are diagnosed with hypertension and $13.3 \%$ of those diagnosed with hypertension do not take medication, and $32.3 \%$ do not take medication regularly. This shows that most hypertensive patients do not know that they suffer from the disease so they do not get treatment. Reasons for hypertension patients not taking medication are because they feel healthy (59.8\%), irregular visits to health care facilities (31.3\%), taking traditional medicine $(14.5 \%)$, using other therapies $(12.5 \%)$, forgetting to take medicine $(11.5 \%)$, not being able to buy drugs ( $8.1 \%$ ), the presence of side effects of drugs (4.5\%), and hypertensive drugs not available in health care facilities $(2 \%)$. Uncontrolled hypertension and lack of treatment for a long time can cause complications in the form of heart, cerebral, kidney and vascular diseases. In addition, it is also influenced by several factors including age, body weight, gender, and so on (Jacob 2006).

Research by the Indonesian Ministry of Health in 2009 showed that the proportion of hypertension in age group 45-54 years and older was always higher than normal with a percentage of $27.7 \%$. The age group of $25-34$ years had a risk of hypertension 1.56 times compared to the age of 18-24 years. The risk of hypertension increased significantly with age and $>75$ years age group had 11.53 times higher risk.

Body Mass Index (BMI) is a risk factor for hypertension. The higher the BMI, the higher the risk of developing hypertension. According to Riskesdas (2013), an increase in one BMI unit can be associated with an increase of $0.56 \mathrm{mmHg}$ systolic and diastolic blood pressure. The results of Leni's research (2012) in Bojonegoro, East Java, also showed an association between overweight and obesity with hypertension.

At present, overweight and obese has become a global health problem. In the world, the incidence of obesity has more than doubled since 1980. In 2014, there were 41 million children who were overweight and obese. In adults, obesity is a risk factor for non-communicable diseases. Non-communicable diseases are now known as the top 10 main killers. As many as 2.8 million people of the world population died due to suffering from non-communicable diseases related to obesity. Usually obesity is found among people in high-income countries, now the same case is also found in low and middle income people in urban areas. This is caused by unhealthy lifestyles and the lack of sports activities. Even though it does not cause sudden death, obesity can be very dangerous if it is let unnoticed.

Obesity is a health problem that needs to be considered as a risk factor for hypertension. In Indonesia, the number of overweight and obesity at the age of 21 years is $21.7 \%$ of the population (Rikesdas, 2010). Overweight and obesity in Indonesia have become major problems that require serious treatment (Roche 2008). Riskesdas data (2013) shows that there are $18.8 \%$ of children aged 5-12 years have overweight. As many as $10.8 \%$ suffer from obesity. The same data also shows the prevalence of obesity in children with comorbidity is closely related to the incidence of obesity in the elderly. Seeing the danger of this disease, obesity is now included in the national medium and long term development plan and the Republic of Indonesia's Ministry of Health strategic plan 2015-2019.

Rahajeng and Tuminah's research in 2009 showed that risk factors significantly related to hypertension were 
old age (OR 11.5 with CI 9.01-9.98), male (OR 1.3 with 95\% CI 1.21-1, 29), low education (OR 1.6 with $95 \%$ CI 1.51-1.71), obesity (OR 2.8 with $95 \%$ CI 2.67-2.91), and abdominal obesity (OR 1.4 with $95 \%$ CI 1.36-1.44). Therefore, research needs to be carried out on the role of age, sex, and BMI on blood pressure.

\section{MATERIALS AND METHODS}

This study was a cross-sectional observational analytic study in which age, sex, BMI, and blood pressure were determined at the same time. The research sample comprised students of class $\mathrm{X}$ and XI of SMAK St. Hendrikus Surabaya in 2013 who were willing to participate in this study. The sample size was 150 students. Based on the formula of Lameshow (1997) the minimum sample size was 73 students. The sampling technique used was consecutive sampling. The independent variables were age, sex, BMI, and nutritional status, while the dependent variable was blood pressure.

Weight (BW) was measured using a spring scale where the respondent stood upright on the scale. Height (BH) was is measured by microtoice where the respondent's head, back, buttocks, and heels were pressed against the wall and parallel line was drawn from the floor to the tip of the head. Based on the measurement results, body mass index (BMI) was calculated as BW (kg)/BH2 (m). Nutritional status was underweight if the BMI was $<18.5$, normal if the BMI between 18.5-24.9, and over if $>25$.
Blood pressure was checked using mercury tensimeter in three times measurements. Intially, the respondents were rested for 10 minutes in a sitting position and the tensimeter was placed at the height of the heart. Blood pressure measurements were carried out three times with a 5 minute break. An average value of three measurements was taken if there were differences in blood pressure values of more than $10 \mathrm{mmHg}$. The measurement results were regarded to be normal if blood pressure $<120 / 80 \mathrm{mmHg}$, pre-hypertension if systolic blood pressure $120-139 \mathrm{mmHg}$ or diastolic blood pressure $80-89 \mathrm{mmHg}$, grade 1 hypertension if systolic blood pressure $140-159 \mathrm{mmHg}$ or diastolic blood pressure $90-99 \mathrm{mmHg}$, and grade 2 hypertension if cystolic blood pressure $>160 \mathrm{mmHg}$ or diastolic blood pressure $>100 \mathrm{mmHg}$ (JNC VII, 2007). Data were analyzed with Pearson's correlation $(?=0.05)$, Spearman $(?=0.05)$ and Chi Square $(?=0.05)$ tests. The level of risk was calculated using epi info program.

\section{RESULTS}

Data processing showed that students with undernutrition status were $31(20.7 \%)$, and overnutrition were 27 students (18\%). The distribution of nutritional status of the students by age showed that most students $(54.8 \%)$ with undernutrition were 16 years old, and students with overnutrition mostly (44.4\%) aged 16 years (Table 1).

Table 1. Distribution of respondents by age and nutritional status

\begin{tabular}{ccccc}
\hline \multirow{2}{*}{$\begin{array}{c}\text { Age } \\
(\mathrm{yrs})\end{array}$} & \multicolumn{3}{c}{ Nutritional Status } & \multirow{2}{*}{ Total } \\
\cline { 2 - 4 } 15 & Under & Normal & Over & \\
16 & $17(25.8 \%)$ & $18(19.6 \%)$ & $5(18.5 \%)$ & $31(20.7 \%)$ \\
17 & $6(19.4 \%)$ & $44(47.8 \%)$ & $12(44.4 \%)$ & $73(48.7 \%)$ \\
18 & $0(0 \%)$ & $26(28.3 \%)$ & $8(29.6 \%)$ & $40(26.7 \%)$ \\
19 & $0(0 \%)$ & $3(3.3 \%)$ & $2(7.4 \%)$ & $5(3.3 \%)$ \\
\hline Total & $31(20.7 \%)$ & $92(61.3 \%)$ & $0(0 \%)$ & $1(0.7 \%)$ \\
\hline
\end{tabular}

Table 2. Distribution of students by age and systolic blood pressure

\begin{tabular}{|c|c|c|c|c|}
\hline \multirow[b]{2}{*}{$\begin{array}{l}\text { Age } \\
\text { (yrs) }\end{array}$} & \multicolumn{3}{|c|}{ Systolic BP } & \multirow[b]{2}{*}{ Total } \\
\hline & $\begin{array}{c}\text { Normal } \\
<120\end{array}$ & $\begin{array}{c}\text { Pre-hypertension } \\
120-139\end{array}$ & $\begin{array}{c}\text { Hypertension } \\
\text { grade } 1(140-159)\end{array}$ & \\
\hline 15 & $25(23.1 \%)$ & $5(12.5 \%)$ & $1(50 \%)$ & $31(20.7 \%)$ \\
\hline 16 & $50(46.3 \%)$ & $22(55 \%)$ & $1(50 \%)$ & $73(48.7 \%)$ \\
\hline 17 & $28(25.9 \%)$ & $12(30 \%)$ & $0(0 \%)$ & $40(26.7 \%)$ \\
\hline 18 & $4(3.7 \%)$ & $1(2.5 \%)$ & $0(0 \%)$ & $5(3.3 \%)$ \\
\hline 19 & $1(0.9 \%)$ & $0(0 \%)$ & $0(0 \%)$ & $1(0.7 \%)$ \\
\hline Total & $108(72 \%)$ & $40(26.7 \%)$ & $2(1.3 \%)$ & $150(100 \%)$ \\
\hline
\end{tabular}


Students with pre-hypertensive systolic blood pressure were $40(26.7 \%)$, and those with grade 1 hypertension were $2(1.3 \%)$. Most (55\%) pre-hypertensive students were 16 years old, then 17 years $(30 \%)$, and 15 years $(12.5 \%)$ (Table 2). Table 3 shows that in students with diastolic blood pressure. those with pre-hypertension were $25.3 \%$ (38 students). while those with grade 1 hypertension were $6.67 \%$ (10 students). BMI has a significant effect $(\mathrm{p}<0.001)$ on systolic blood pressure, while Spearman correlation test $(\alpha=0.05)$ also shows that BMI has a significant influence $(\mathrm{p}<0.001)$ on diastolic blood pressure with moderate strength of correlation (Table 4).

Spearman's correlation test $(\alpha=0.05)$ also showed that the students's age did not have a significant influence $(\mathrm{p}=0.623)$ on systolic blood pressure, but had a significant influence $(\mathrm{p}=0.002)$ on systolic blood pressure with a correlation strength of 0.256 (weak) (Table 5). Chi-Square test $(\alpha=0.05)$ showed a significant influence ( $\mathrm{p}<0.001)$ of male sex on students' systolic blood pressure (Table 6). The same test also showed that sex had a significant influence $(p=0.007)$ on diastolic blood pressure of the students.

The risk of male sex for pre-hypertension and grade 1 systolic hypertension is estimated by relative risk (RR) as can be seen in Table 8 . The risk of male sex for prehypertension and grade 1 systolic hypertension was 5.36 times higher than of female sex (Table 8). The risk of male sex for pre-hypertension and grade 1 diastolic hypertension was estimated by relative risk (RR) (Table 9).

Table 3. Distribution of students by age and diastolic blood pressure

\begin{tabular}{ccccc}
\hline \multirow{2}{*}{$\begin{array}{c}\text { Age } \\
(\text { yrs })\end{array}$} & \begin{tabular}{c} 
Dormal \\
\cline { 2 - 4 }
\end{tabular} & $\begin{array}{c}\text { Pre-hypertension } \\
\text { <80 }\end{array}$ & $\begin{array}{c}\text { Hypertension } \\
\text { grade 1(90-9 9) }\end{array}$ & Total \\
\hline 15 & $27(26.5 \%)$ & $3(7.9 \%)$ & $1(10 \%)$ & $31(20.7 \%)$ \\
16 & $51(50 \%)$ & $17(44.7 \%)$ & $5(50 \%)$ & $73(48.7 \%)$ \\
17 & $21(20.6 \%)$ & $15(39.5 \%)$ & $4(40 \%)$ & $40(26.7 \%)$ \\
18 & $2(2 \%)$ & $3(7.9 \%)$ & $0(0 \%)$ & $5(3.3 \%)$ \\
19 & $1(1 \%)$ & $0(0 \%)$ & $0(0 \%)$ & $1(0.7 \%)$ \\
\hline Total & $102(68 \%)$ & $38(25.3 \%)$ & $10(6.7 \%)$ & $150(100 \%)$ \\
\hline
\end{tabular}

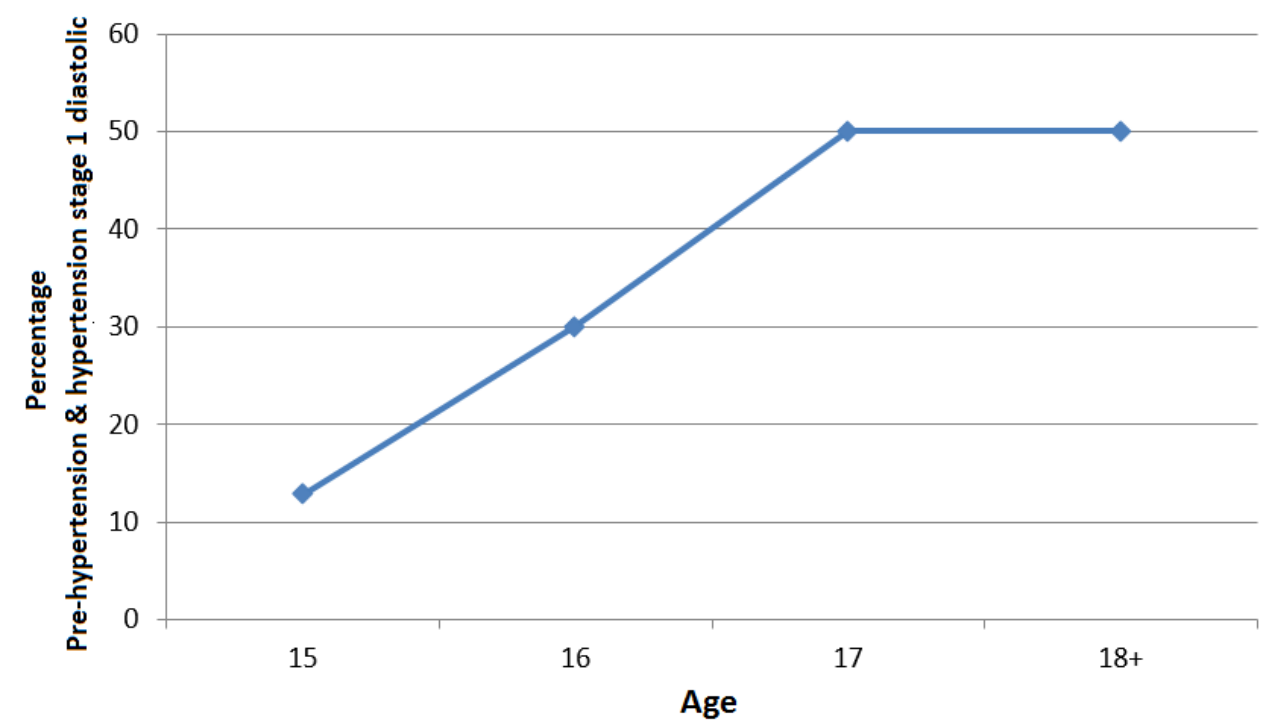

Fig. 1. Trend of an increase in diastolic blood pressure by age. 
Table 4. Influence of BMI on blood pressure

\begin{tabular}{ccccc}
\hline Influence & $\mathrm{n}$ & Correlation & $\begin{array}{c}\text { Correlation } \\
\text { Coefficient }\end{array}$ & P Value \\
\hline BMI with Systolic blood pressure & 150 & Pearson & 0.513 & $<0.001$ \\
BMI with Diastolic blood pressure & 150 & Spearman & 0.429 & $<0.001$ \\
\hline
\end{tabular}

Table 5. Influence of age on blood pressure

\begin{tabular}{lccc}
\hline Influence & $\mathrm{n}$ & Spearman Correlation Coefficient & P Value \\
\hline Age with systolic blood pressure & 150 & 0.040 & 0.623 \\
Age with diastolic blood pressure & 150 & 0.255 & 0.002 \\
\hline
\end{tabular}

Table 6. Influence of sex on systolic blood pressure

\begin{tabular}{cccccc}
\hline \multirow{2}{*}{ Sex } & \multicolumn{3}{c}{ Systolic blood pressure } & \multirow{2}{*}{ Total } & P Value \\
\cline { 2 - 4 } & Normal & Pre-hypertension & $\begin{array}{c}\text { Hypertension } \\
\text { grade } 1\end{array}$ & & \\
\hline Male & $50(46.3 \%)$ & $35(87.5 \%)$ & $2(100 \%)$ & $87(58 \%)$ & \\
Female & $58(53.7 \%$ & $5(12.5 \%)$ & $0(0 \%)$ & $63(42 \%)$ & $<0.001$ \\
\hline Total & $108(72 \%)$ & $40(26.7 \%)$ & $2(1.3 \%)$ & $150(100 \%)$ & \\
\hline
\end{tabular}

Table 7. Influence of sex on diastolic blood pressure

\begin{tabular}{cccccc}
\hline \multirow{2}{*}{ Sex } & \multicolumn{3}{c}{ Diastolic blood pressure } & \multirow{2}{*}{ Total } & P Value \\
\cline { 2 - 4 } & Normal & Pre-hypertension & $\begin{array}{c}\text { Hypertension } \\
\text { grade } 1\end{array}$ & & \\
\hline Male & $52(51 \%)$ & $26(68.4 \%)$ & $9(90 \%)$ & $87(58 \%)$ & \\
Female & $50(49 \%$ & $12(31.6 \%)$ & $1(10 \%)$ & $63(42 \%)$ & 0.007 \\
\hline Total & $102(68 \%)$ & $38(25.3 \%)$ & $10(6.7 \%)$ & $150(100 \%)$ & \\
\hline
\end{tabular}

Table 8. Level of risk of male sex for systolic blood pressure

\begin{tabular}{|c|c|c|c|c|}
\hline \multirow[b]{2}{*}{ Sex } & \multicolumn{2}{|c|}{ Systolic blood pressure } & \multirow[b]{2}{*}{ Total } & \multirow{2}{*}{$\begin{array}{c}\mathrm{RR} \\
(95 \% \mathrm{CI})\end{array}$} \\
\hline & Normal & $\begin{array}{c}\text { Pre-hypertension \& } \\
\text { Hypertension grade } 1\end{array}$ & & \\
\hline Male & $37(42.5 \%)$ & $50(57.5 \%)$ & $87(100 \%)$ & \multirow{3}{*}{$\begin{array}{c}5.36 \\
(2.232-12.865)\end{array}$} \\
\hline Female & $5(7.9 \%)$ & $58(92.1 \%)$ & $63(100 \%)$ & \\
\hline Total & $42(28 \%)$ & $108(72 \%)$ & $150(100 \%)$ & \\
\hline
\end{tabular}

Table 9. Level of risk of male sex for diastolic blood pressure

\begin{tabular}{|c|c|c|c|c|}
\hline \multirow[b]{2}{*}{ Sex } & \multicolumn{2}{|c|}{ Diastolic blood pressure } & \multirow[b]{2}{*}{ Total } & \multirow[b]{2}{*}{$\begin{array}{c}\mathrm{RR} \\
(95 \% \mathrm{CI})\end{array}$} \\
\hline & Normal & $\begin{array}{l}\text { Pre-hypertension \& } \\
\text { Hypertension grade } 1\end{array}$ & & \\
\hline Male & $35(40.2 \%)$ & $52(59.8 \%)$ & $87(100 \%)$ & \multirow{3}{*}{$\begin{array}{c}1.95 \\
(1.127-3.372)\end{array}$} \\
\hline Female & $13(20.6 \%)$ & $50(79.4 \%)$ & $63(100 \%)$ & \\
\hline Total & $48(28 \%)$ & $102(72 \%)$ & $150(100 \%)$ & \\
\hline
\end{tabular}


Table 10. Distribution of systolic blood pressure by nutritional status

\begin{tabular}{lcccc}
\hline \multirow{2}{*}{ Systolic blood pressure } & \multicolumn{3}{c}{ Nutritional Status } & \multirow{2}{*}{ Total } \\
\cline { 2 - 4 } & Under & Normal & Overweight & \\
\hline$<120$ & $26(83.9 \%)$ & $69(75 \%)$ & $13(48.1 \%)$ & $108(72 \%)$ \\
$120-139$ & $5(16.1 \%)$ & $23(25 \%)$ & $12(44.4 \%)$ & $40(26.7 \%)$ \\
$140-159$ & $0(0 \%)$ & $0(0 \%)$ & $2(7.4 \%)$ & $2(1.3 \%)$ \\
\hline Total & $31(20.7 \%)$ & $92(61.3 \%)$ & $27(18 \%)$ & $150(100 \%)$ \\
\hline
\end{tabular}

Table 11. Distribution of diastolic blood pressure by nutritional status

\begin{tabular}{lcccc}
\hline \multirow{2}{*}{ Diastolic blood pressure } & \multicolumn{3}{c}{ Nutritional Status } & \multirow{2}{*}{ Total } \\
\cline { 2 - 4 } & Under & Normal & Overweight & \\
\hline$<80$ & $28(90.3 \%)$ & $65(70.7 \%)$ & $9(33.3 \%)$ & $102(68 \%)$ \\
$80-89$ & $3(9.7 \%)$ & $22(23.9 \%)$ & $13(48.1 \%)$ & $38(25.3 \%)$ \\
$90-99$ & $0(0 \%)$ & $5(5.4 \%)$ & $5(18.5 \%)$ & $10(6.7 \%)$ \\
\hline Total & $31(20.7 \%)$ & $92(61.3 \%)$ & $27(18 \%)$ & $150(100 \%)$ \\
\hline
\end{tabular}

Table 12. Influence of nutritional status on blood pressure

\begin{tabular}{cccc}
\hline Influence & $\mathrm{n}$ & $\begin{array}{c}\text { Spearman Correlation } \\
\text { Coefficient }\end{array}$ & P Value \\
\hline Nutritional Status with systolic blood pressure & 150 & 0.250 & 0.002 \\
Nutritional Status with diastolic blood pressure & 150 & 0.382 & $<0.001$ \\
\hline
\end{tabular}

Table 13. Risk of nutritional status on systolic blood pressure

\begin{tabular}{|c|c|c|c|c|}
\hline \multirow[b]{2}{*}{$\begin{array}{l}\text { Nutritional } \\
\text { Status }\end{array}$} & \multicolumn{2}{|c|}{ Systolic blood pressure } & \multirow[b]{2}{*}{ Total } & \multirow[b]{2}{*}{$\begin{array}{c}\mathrm{RR} \\
(95 \% \mathrm{CI})\end{array}$} \\
\hline & Normal & $\begin{array}{l}\text { Pre-hypertension } \\
\text { \& Hypertension } \\
\text { grade } 1\end{array}$ & & \\
\hline Overweight & $14(51.9 \%)$ & $13(48.1 \%)$ & $27(100 \%)$ & \multirow{3}{*}{$\begin{array}{c}2.278 \\
(1.398-3.710)\end{array}$} \\
\hline $\begin{array}{l}\text { Under \& } \\
\text { Normal }\end{array}$ & $28(22.8 \%)$ & $95(77.2 \%)$ & $123(100 \%)$ & \\
\hline Total & $42(28 \%)$ & $108(72 \%)$ & $150(100 \%)$ & \\
\hline
\end{tabular}

Table 14. Level of risk of nutritional status on diastolic blood pressure

\begin{tabular}{|c|c|c|c|c|}
\hline \multirow[b]{2}{*}{$\begin{array}{l}\text { Nutritional } \\
\text { Status }\end{array}$} & \multicolumn{2}{|c|}{ Diastolic blood pressure } & \multirow[b]{2}{*}{ Total } & \multirow[b]{2}{*}{$\begin{array}{c}\mathrm{RR} \\
(95 \% \mathrm{CI})\end{array}$} \\
\hline & Normal & $\begin{array}{c}\text { Pre-hypertension } \\
\text { \& Hypertension } \\
\text { grade } 1\end{array}$ & & \\
\hline Overweght & $18(66.7 \%)$ & $9(33.3 \%)$ & $27(100 \%)$ & \multirow{3}{*}{$\begin{array}{c}2.733 \\
(1.814-4.118)\end{array}$} \\
\hline $\begin{array}{l}\text { Under \& } \\
\text { Normal }\end{array}$ & $30(24,4 \%)$ & $93(75,6 \%)$ & $123(100 \%)$ & \\
\hline Total & $48(28 \%)$ & $102(72 \%)$ & $150(100 \%)$ & \\
\hline
\end{tabular}

The risk of male sex for pre-hypertension and grade 1 diastolic hypertension was 1.95 times compared to female sex. Of 150 students, $18 \%$ had overnutrition and $51.8 \%$ had pre-hypertension to grade 1 hypertension. A total of $66.7 \%$ (18 people) of students who were overweight suffered from pre-hypertension to diastolic grade 1 hypertension (Table 11). Based on Spearman correlation test $(?=0.05)$, nutritional status had a significant effect $(\mathrm{p}=0.002)$ on systolic blood pressure, as well as a significant effect $(\mathrm{p}<0.001)$ on diastolic blood pressure (Table 12). The risk of nutritional status for pre-hypertension and grade 1 systolic hypertension was estimated by relative risk (RR) as can be seen in Table 13. Students with overnutrition status had a risk 
of getting pre-hypertension and grade 1 systolic hypertension by 2,278 times compared to students with normal and undernutrition status.

The risk of nutritional status for prehypertension and grade 1 diastolic hypertension was obtained by estimating RR (Table 14). Students with overnutrition status had 2.733 times the risk of pre-hypertension and grade 1 diastolic hypertension compared to those with normal and undernutrition status.

\section{DISCUSSION}

Students who were overweight (BMI >25) were $18 \%$, and $66.7 \%$ of them suffered from pre-hypertension to grade 1 hypertension. Of the 150 students, those who suffered from systolic pre-hypertension were $26.7 \%$, and grade 1 systolic hypertension $1.3 \%$, while those with diastolic pre-hypertension were $25.3 \%$, and grade 1 diastolic hypertension $6.7 \%$.

Descriptively, the results of this study indicated that the trend for pre-hypertension to diastolic grade 1 hypertension increased with age. Age had a significant effect $(p=0.002)$ on diastolic blood pressure. The older the age, the more rigid the blood vessels, so that peripheral resistance increases. This condition is consistent with the results of a 2009 Ministry of Health study, which showed that the proportion of hypertension in age group 45 - 54 years and older was always higher than those with normotension in a percentage of $27.7 \%$. The age group of 25-34 years had a risk of hypertension 1.56 times higher compared to the age of 18-24 years. The risk of hypertension increases significantly with increasing age, and the age group $>75$ years has a risk of 11.53 times higher.

In this study, male sex was proven to be a risk factor for pre-hypertension to grade 1 systolic or diastolic hypertension. Male sex had level of risk of prehypertension to grade 1 systolic hypertension 5.36 times higher compared to women, and the risk of prehypertension to grade 1 diastolic hypertension 1.95 times higher compared to women. Factors that play a role in men are likely smoking, drinking alcohol, stress, type A personality and so forth.

In this study, BMI had a significant effect $(\mathrm{p}<0.001)$ on blood pressure. This was in accordance with the results of Zazariani's research (2011) which showed there was correlation $(p=0.02)$ between BMI and the incidence of increased blood pressure. The results of Leni's research (2012) in Bojonegoro, Indonesia, also showed an association between being overweight and obesity with hypertension.
Weight and BMI correlate directly with blood pressure, especially systolic blood pressure. The relative risk for suffering from hypertension in obese people is 5 times higher compared to individuals with normal weight. About $20-30 \%$ of hypertensive individuals are overweight (Sutanto 2010)

The higher the BMI, the higher the systolic and/or diastolic blood pressure. The higher the body mass, the more blood is needed to supply oxygen and food to body tissues. This means that the volume of blood circulating through blood vessels increases so that it puts more pressure on artery walls. Being overweight also increases heart rate frequency and insulin levels in blood. Increased insulin causes the body to retain sodium and water (Theodosha et al 2000).

Individuals with overnutrition status have a risk of developing grade 1 systolic pre-hypertension and hypertension by 5.36 times compared to individuals with normal and undernutrition status, and have a risk of pre-hypertension and grade 1 diastolic hypertension by 1.95 times compared to individuals with normal and undernutrition status. Hypertension in obesity is the result of interaction of several factors, ie. food consumption habits, genetic, epigenetic, and environmental factors. The failure of adipocyte function in obese patients causes vascular and insulin resistance. This will cause failure of sympathetic nerve function and the renin angiotensin system which play a role in the development of hypertension (DeMarco et al 2014). Rahajeng and Tuminah's research results in 2009 showed that risk factors significantly related to hypertension were old age (OR 11.5 with CI 9.01-9.98), male (OR 1.3 with CI 1.21-1.29), low education (OR 1.6 with CI 1.51-1.71), obesity (OR 2.8 with CI 2.672.91), and abdominal obesity (OR 1.4 with CI 1.36 $1.44)$.

\section{CONCLUSION}

The trend for pre-hypertension to grade 1 diastolic hypertension increases with age and age has influence on diastolic blood pressure. The risk of males to suffer from pre-hypertension to grade 1 systolic hypertension is 5.36 times that of women, and the risk of prehypertension to grade 1 diastolic hypertension is 1.95 times that of women. The higher the BMI, the higher the systolic and/or diastolic blood pressure. Being overweight has a risk of pre-hypertension to grade 1 systolic (RR 2,278) or diastolic (RR 2,273) hypertension. 


\section{ACKNOWLEDGMENT}

We thank, 1) the Head of SMAK St. Hendrikus, Surabaya, who had allowed his students to participate as samples in this research, 2) dr. Sakina and nurse Ida who had assisted the authors in data collection, 3) Atika, SSi, M.Kes who had assisted the authors in data analysis, 4) students of class X-XI at SMAK St. Hendrikus Surabaya in 2013 who were willing to participate in this research.

\section{REFERENCES}

DeMarco VG, Aroor AR, Sowers JR (2014). The pathophysiology of hypertension in patients witobesity. Nature Reviews Endocrinology 10

Departemen Kesehatan Republik Indonesia (2013). Riset Kesehatan Dasar (Riskesdas) Tahun 2013. Available at http://www.litbang.depkes.go.id/sites/ Riskesdas

The Institute for Health Metrics and Evaluation (IHME) (2017). Cardiovascular disease causes one-third of deaths worldwide. Available at http://www.healthdata.org/news-release/cardiovascular-disease-causesone-third-deaths-worldwide

Jacob DR (2006). Fast food and sedentary lifestyle: a combination that leads to obesity. American Journal of Clinical Nutrition. February 83, 189-190

Leni S (2012). Hubungan obesitas dengan kejadian hipertensi pada masyarakat di Desa Gayam, Kecamatan Ngasem, Kabupaten Bojonegoro. Available at http://share.stikesyarsis.ac.id/elib/main/ dok/00745/hubungan-obesitas-dengan- kejadian-hipertensi-pada-masyarakat-di-desa-gayam-kecamatanngasem-kabupaten- Bojonegoro. Accessed October 11,2013

Rahajeng E, Tuminah S (2009). Prevalence of hypertension and its determinants in Indonesia. Majalah Kedokteran Indonesia 59. Available at http://indonesia.digitaljournals.org/index.php/idnmed/ article/view/700. Accessed October 11, 2013

Roche (2008). Kelebihan berat badan dan obesitas. Available at http://www.roche.co.id/fmfiles/re717 5008/Indonesian/media/lembar.informasi/M_n_R/obes itas/Lembar. Informasi.Berat.Badan.dan.Obesitas.pdf. Accessed October 7, 2013

Sutanto (2010). Cekal (cegah dan tangkal) penyakit modern: hipertensi, stroke, jantung, kolesterol, dan diabetes (gejala-gejala, pencegahan dan pengendalian). Yogyakarta, ANDI

Theodosha SG, Lackland BE, Woolson R (2000). Effect of total obesity and abdominal obesity on hypertension. Medical University of Southcaroline

WHO (2015). WHO global strategy on diet, physical activity and health: childhood overweight and obesity.World Health Organization 2015. Available at http://www.who.int/dietphysicalactivity/childhood/en/. Accessed October 11, 2013

Zazariani S (2012). Hubungan antara aktifitas fisik dan obesitas dengan kejadian hipertensi pada umur 20-44 tahun di puskesmas depok maguwoharjo kabupaten sleman. Available at http://e-journal.respati.ac.id/ sites/default/files/2012-VI-18TeknologiInformasi/ Jurnal\%20Serliana\%20Zazariani\%20Japi.docx. Accessed October 11, 2013 